\title{
Trophic modes of large Antarctic Foraminifera: roles of carnivory, omnivory, and detritivory
}

\author{
Stephanie B. Suhr ${ }^{1,2,6, * *}$, Stephen P. Alexander ${ }^{1,3}$, Andrew J. Gooday ${ }^{2}$, \\ David W. Pond ${ }^{2,4}$, Samuel S. Bowser ${ }^{3,5, *, * *}$ \\ ${ }^{1}$ Raytheon Polar Services Co, 7400 S. Tucson Way, Centennial, Colorado 80112, USA \\ ${ }^{2}$ National Oceanography Centre, Southampton, University of Southampton Waterfront Campus, European Way, \\ Southampton SO14 3ZH, UK \\ ${ }^{3}$ Wadsworth Center, New York State Department of Health, Albany, New York 12201, USA \\ ${ }^{4}$ British Antarctic Survey, Biological Sciences Division, Madingley Road, Cambridge CB3 0ET, UK \\ ${ }^{5}$ Department of Biomedical Sciences, School of Public Health, The University at Albany, State University of New York, \\ Albany, New York 12201, USA \\ ${ }^{6}$ Present address: Inter-Research, Nordbünte 23, 21385 Oldendorf/Luhe, Germany
}

\begin{abstract}
Astrammina rara, Crithionina delacai, and Notodendrodes hyalinosphaira are 3 of the largest and most abundant members of the foraminiferal assemblage at a shallow-water (28 to $32 \mathrm{~m}$ ) site in Explorers Cove, Antarctica. This study summarizes observations from 2 decades of research, during which we employed laboratory-based feeding experiments and fatty acid biomarker analysis to characterize trophic dynamics and ecological roles of the 3 species. In feeding experiments, A. rara consumed a variety of co-occurring metazoans (several Crustacea, Mollusca, Echinodermata, and a Nephtys species). C. delacai, $N$. hyalinosphaira, and a number of other foraminiferal species from Explorers Cove successfully trapped Artemia sp. nauplius prey in a setup designed to examine the efficiency of prey capture. Fatty acid analyses on samples from early (November 7, 2001) and late (January 31, 2002) austral summer revealed that the 3 species contained substantial amounts (33 to $45.5 \%$ ) of polyunsaturated fatty acids (PUFAs), which are produced by microalgae, indicating the downwards transfer of carbon from sea-ice associated primary production. In the case of A. rara, this may be due to the ingestion of herbivorous metazoa, rather than direct uptake of microalgal material. A. rara contained significantly $(\mathrm{p}<0.05)$ higher amounts of the zooplankton biomarkers $20: 1(\mathrm{n}-9)$ and 22:1(n-11), and C. delacai contained more PUFAs early, compared to late, in the season. Two morphotypes of $N$. hyalinosphaira had different fatty acid profiles, indicating distinct trophotypes. Our results illustrate specific adaptations to different trophic resources in these protists, and they demonstrate the potential impact that large carnivorous species of Foraminifera may have on the structure of benthic communities where they are abundant.
\end{abstract}

KEY WORDS: Foraminifera $\cdot$ Trophic ecology $\cdot$ Benthic $\cdot$ Food web $\cdot$ Carnivory $\cdot$ Antarctic $\cdot$ Explorers Cove $\cdot$ Community structure

\section{INTRODUCTION}

Foraminiferans are arguably the most diverse and abundant protists in the marine realm. Calcareous and agglutinated species often constitute a substantial proportion and biomass of benthic communities in deep-sea and polar environments (Basov 1974, DeLaca et al. 1981, Thiel 1983, Smith et al. 2002). Recently, the abundance and diversity of previously overlooked, soft-shelled species, which can account for 10 to $20 \%$ of Foraminifera in deep-sea sediments, have become evident (Gooday 2002). An increasing number of studies is revealing the ecological significance of this group of protists (Gooday et al. 1992, Moodley et al. 2002, 
Suhr et al. 2003, Suhr \& Pond 2006). Given that Foraminifera are a major component of marine meio- and macrofaunal communities and have a very long geological history, their trophic mechanisms are of considerable importance in understanding modern and ancient benthic food webs (Lipps \& Valentine 1970, Lipps 1983, Goldstein 1999). The present study focuses on the large agglutinated species Astrammina rara, Crithionina delacai and Notodendrodes hyalinosphai$r a$, which are accessible to SCUBA divers at 28 to $32 \mathrm{~m}$ depth under sea ice at a site in Explorers Cove, Antarctica. At this site, densities of large Foraminfera (airlift samples of 0 to $1 \mathrm{~cm}$ surface sediment layer, total population $>500 \mu \mathrm{m}$ ) can reach up to 6810 ind. $\mathrm{m}^{-2}$ (Gooday et al. 1996). Specimens of A. rara can grow up to a diameter of $4.5 \mathrm{~mm}$, with an average diameter of $2.1 \mathrm{~mm}$. C. delacai may reach up to $6.5 \mathrm{~mm}$ in diameter and abundances of up to 2527 ind. $\mathrm{m}^{-2}$ in airlift samples, which include specimens larger than 1000 $\mu \mathrm{m}$ (Gooday et al. 1995). Finally, the agglutinated species $N$. hyalinosphaira occurs as 2 different morphotypes. The primary test is a shallow infaunal, unilocular sphere consisting of a single layer of sand grains, mainly quartz, which can either be covered with a thick layer of fine detrital material or else have 1 (rarely 2) 'daisy-shaped' appendage that protrudes vertically into the water column. In the latter 'treemorph' form, specimens of $N$. hyalinosphaira attain a maximum length of up to $2.7 \mathrm{~cm}$ (DeLaca et al. 2002). Most specimens of $N$. hyalinosphaira are found as 'quartz balls' (Gooday et al. 1996).

Initial results from laboratory studies of these 3 conspicuous members of the Explorers Cove foraminiferal assemblage suggested radically different trophic modes. Astrammina rara was previously observed to consume Artemia sp. nauplii under laboratory conditions (Bowser et al. 1986, 1992). However, it remained unclear as to whether or not A. rara consumes co-occurring metazoan species and whether carnivory occurs in situ. Scanning electron microscopic observations revealed diatom spicules in the cell body of Crithionina delacai (Gooday et al. 1995). Earlier, radiotracer studies on the related species Notodendrodes antarkticos (DeLaca et al. 1981, DeLaca 1982, Rivkin \& DeLaca 1990) implicated osmotrophy as a major trophic mechanism in the treemorph of $N$. hyalinosphaira. DeLaca et al. (2002) suggested that the secondary test features of this species reflect different trophic modes, ranging from the infaunal uptake of dissolved nutrients in the case of the quartz balls to suspension feeding in the tree form. We report the results of additional field and laboratory studies aimed at better describing the trophic habits of these foraminifers, and we discuss the organisms' roles in the benthic community at Explorers Cove and in a wider context.

\section{MATERIALS AND METHODS}

Study site and sample collection. The study site and collection methods have been detailed elsewhere (Gooday et al. 1996). Briefly, the silty sand seafloor at Explorers Cove, Antarctica was sampled by SCUBA divers using an airlift apparatus (Pollock \& Bowser 1995). Specimens of the tree-morph of Notodendrodes hyalinosphaira were recovered by divers using handheld coring devices.

Feeding experiments. Viability of specimens selected for the experiments was determined by direct microscopic observation of pseudopodial activity. Two types of feeding experiments were conducted according to the methods described by Bowser et al. (1992). To determine the range of possible prey items of Astrammina rara, we kept specimens in Petri dishes at in situ temperatures and offered them a range of co-occurring metazoa in austral winter 1986. In a second experiment carried out in November 2006, the prey capture efficiency of a number of foraminiferal species in Explorers Cove was assessed as a function of the number of Artemia sp. meta-nauplii (hereafter Artemia) trapped by each specimen. In this case, all specimens were kept in Petri dishes, with the exception of the Notodendrodes hyalinosphaira tree-morph, which was incubated with nauplii in undisturbed $7.4 \mathrm{~cm}$ diameter cores (in an effort to preserve in situ conditions). Artemia specimens were added at densities up to $1 \mathrm{ml}$ and incubated overnight (i.e. up to $12 \mathrm{~h}$ ). Prey capture efficiency was described by assigning individuals to 3 different categories: specimens with $\geq 10$ attached Artemia nauplii were considered to possess high prey capture efficiency, $<10$ nauplii attached meant lower prey capture efficiency, and specimens without attached nauplii fell into the final category (no prey capture observed). Specimen preparation for electron microscopy was detailed by Bowser \& Travis (2000).

Fatty acid biomarker analysis. Samples for fatty acid biomarker analysis of Astrammina rara and Crithionina delacai were taken during the early (November 7 , 2001) and late (January 31, 2002) austral summer season. After collection, specimens were sorted, snapfrozen in liquid nitrogen, and stored in $1 \mathrm{ml}$ cryovials at $-80^{\circ} \mathrm{C}$. Five specimens each of A. rara and C. delacai were analyzed from the early and late sampling occasions. The 2 Notodendrodes hyalinosphaira morphotypes were available only from early season samples. From these samples, 5 specimens of the quartz ball and 3 of the tree-morphs were analyzed. In addition, one specimen each of a co-occurring amphipod and a pycnogonid species were analyzed. Fatty acid biomarker analyses were conducted as described previously (Suhr et al. 2003). Biomarker fatty acid contents were converted from mol \% to weight \%, and univariate sta- 
tistical analyses (Kruskal-Wallis ANOVA) were conducted on arcsine transformed data. Multivariate statistical analyses (multidimensional scaling and pairwise comparisons via Analysis of Similarities [ANOSIM]) were carried out on transformed data using the PRIMER version 5.1 software (Carr 2001).

\section{RESULTS}

\section{Feeding experiments}

Feeding experiments showed that Astrammina rara ingests a wide range of co-occurring metazoan prey (Table 1), including small $(<1 \mathrm{~cm})$ crustaceans, mollusks, annelids, and juvenile echinoderms. Only the mollusk Margarella sp. and larvae of the ciliated asteroid Acodontaster sp. were not captured, even after prolonged ( $>1 \mathrm{wk}$ ) incubation with the viable foraminifer. In no case was $A$. rara consumed by the metazoans. Results from the prey capture efficiency study (Table 2) show that Astrammina triangularis, Notoden-

Table 1. Astrammina rara. Metazoan prey captured and killed in the laboratory in austral summer 1986. Foraminiferal and metazoan specimens were collected from Explorers Cove and near McMurdo station ('sp. 1, sp. 2, sp. 3, sp. 4' distinguish species that were not further identified)

\begin{tabular}{|c|c|c|}
\hline Species & $\begin{array}{l}\text { Number of } \\
\text { specimens } \\
\text { offered }\end{array}$ & $\begin{array}{l}\text { Number of } \\
\text { specimens } \\
\text { consumed }\end{array}$ \\
\hline \multicolumn{3}{|l|}{ Crustacea } \\
\hline Eudorella splendida & 36 & 31 \\
\hline Cumacean sp. 2 & 10 & 6 \\
\hline Austrosignum grandis & 12 & 9 \\
\hline Echinozone cf. magnifica & 4 & 4 \\
\hline Muna sp. 3 & 8 & 5 \\
\hline Isopod sp. 4 & 4 & 1 \\
\hline Nototanais dimorphus (o \& $0^{7}$ ) & 9 & 7 \\
\hline Amphipod sp. 1 & 7 & 3 \\
\hline Amphipod sp. 2 & 5 & 1 \\
\hline Ostracod sp. 1 & 5 & 5 \\
\hline Ostracod sp. 2 & 1 & 1 \\
\hline \multicolumn{3}{|l|}{ Mollusca } \\
\hline Cuspidaria sp. & 5 & 5 \\
\hline Bivalve sp. 2 & 8 & 8 \\
\hline Limatula hodgsoni & 2 & 2 \\
\hline Margarella sp. & 3 & 0 \\
\hline Gastropod sp. 2 & 4 & 3 \\
\hline \multicolumn{3}{|l|}{ Echinodermata } \\
\hline Abatus sp. & 3 & 3 \\
\hline Sterechinus neumayeri juvenile & 2 & 2 \\
\hline S. neumayeri larvae & 2 & 2 \\
\hline Odontaster validus juvenile & 1 & 1 \\
\hline O. validus larvae & 2 & 1 \\
\hline Acodontaster larvae & 4 & 0 \\
\hline \multicolumn{3}{|l|}{ Annelida } \\
\hline Nephtys sp. juveniles & 1 & 1 \\
\hline
\end{tabular}

drodes antarctikos, Notodendrodes hyalinosphaera, Pilulina sp., and the calcareous foraminifers Pyrgo peruviana and Cornuspira antarctica were highly efficient in trapping the metazoa offered, whereas Crithionina delacai and Gloiogullmia sp. had lower efficiencies in prey capture. In some cases, Artemia sp. nauplii were clearly ensnared within pseudopodial networks extending from the test, as shown previously for A. rara (Bowser et al. 1992). A. rara readily captured nauplii of all sizes and swimming ability and to such an extent that all offered prey were ultimately captured (see also Bowser et al. 1992). In other species (e.g. Notodendrodes spp.), prey were seen clustered around certain portions of the test, while other areas were devoid of prey (Fig. 1A). Closer inspection via scanning electron microscopy (SEM) confirmed that pseudopodial networks were restricted to certain areas of the test surface, consistent with the qualitative observations of prey attachment patterns from light microscopy (Fig. 1B). Nauplii were not seen to be trapped by 2 dead specimens of Pilulina sp., nor by Gromia sp., a related rhizarian protist.

\section{Fatty acid biomarker analysis}

Astrammina rara, Crithionina delacai and Notodendrodes hyalinosphaira (both morphotypes) contained substantial amounts (33 to $45.5 \%$ ) of polyunsaturated fatty acids (PUFAs) (Tables $3 \& 4$ ). PUFAs are produced in large amounts by microplanktonic organisms such as diatoms and flagellates, and can serve as bioindica-

Table 2. Astrammina rara. Results of feeding experiments with Artemia sp. nauplii. Total no. of foram specimens: number of specimens of each foramineran species that fell into each of the defined prey capture efficiency categories. (+++) Heavily labeled Foraminifera, $\geq 10$ Artemia attached, high prey capture efficiency; $(+)<10$ Artemia attached, lower prey capture efficiency; (-) not labelled, no Artemia attached

\begin{tabular}{|c|c|c|c|c|}
\hline Species & $\begin{array}{l}\text { Total no. } \\
\text { of foram } \\
\text { specimens }\end{array}$ & $\begin{array}{r}\text { Prey } \\
\text { effi } \\
(+++)\end{array}$ & $\begin{array}{l}\text { capt } \\
\text { cienc } \\
(+)\end{array}$ & $\begin{array}{l}\text { ure } \\
\text { cy } \\
(-)\end{array}$ \\
\hline Notodendrodes hyalinosphaira & 8 & 8 & 0 & 0 \\
\hline Crithionina delacai ${ }^{\mathrm{a}}$ & 30 & 5 & 11 & 14 \\
\hline Astrammina triangularis & 17 & 17 & 0 & 0 \\
\hline Notodendrodes antarctikos & 4 & 4 & 0 & 0 \\
\hline Pilulina sp. & 8 & 6 & 0 & $2^{1}$ \\
\hline Gloiogullmia sp. & 18 & 0 & 6 & 12 \\
\hline Pyrgo peruviana & 7 & 7 & 0 & 0 \\
\hline Cornuspira antarctica & 5 & 5 & 0 & 0 \\
\hline Gromia sp. & 120 & 0 & 0 & 120 \\
\hline
\end{tabular}



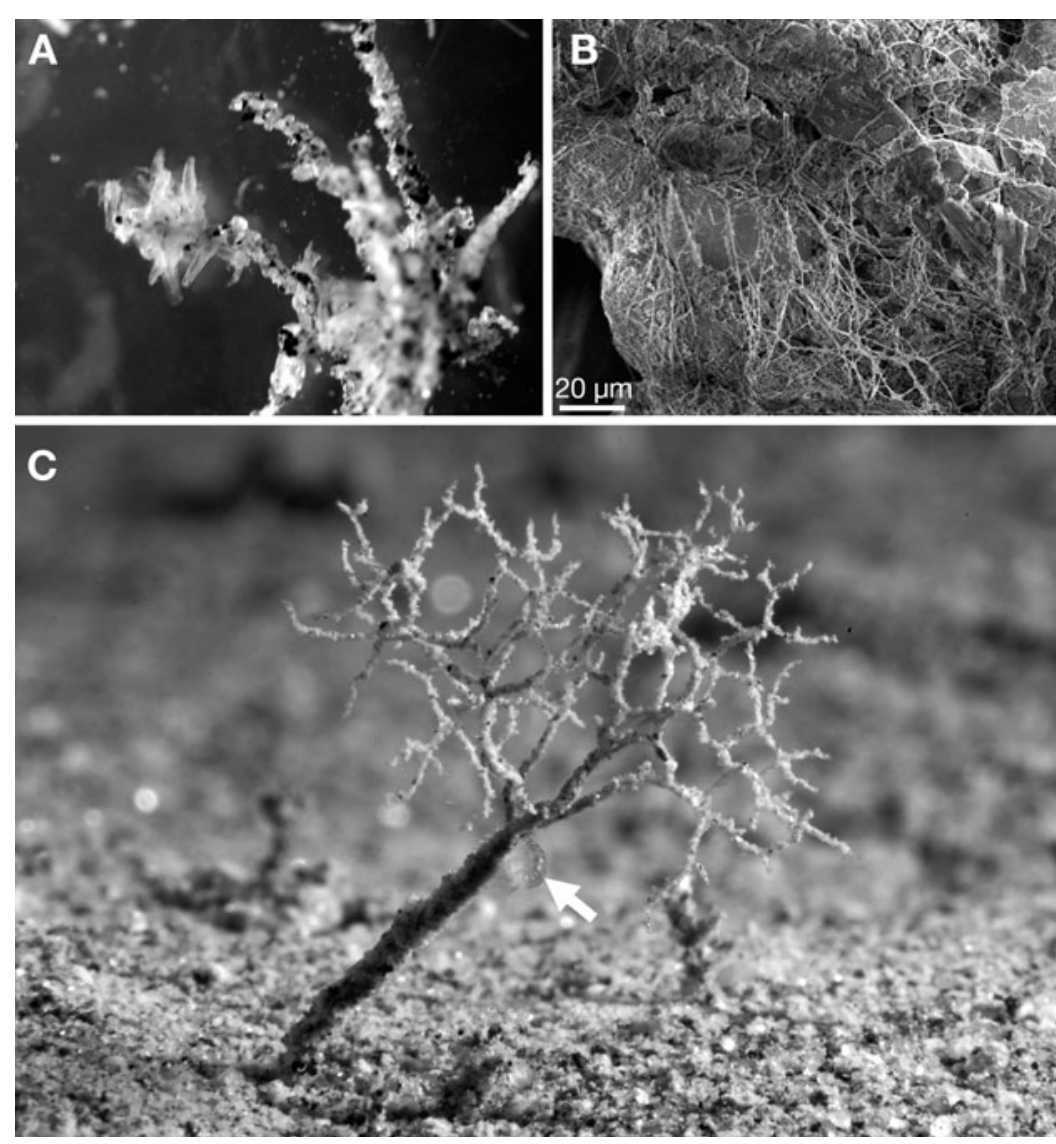

Fig. 1. Notodendrodes hyalinosphaira and N. antarctikos. (A) Light micrograph of Artemia salina nauplii captured on the above-surface 'tree' portion of $N$. hyalinosphaira. (B) Scanning electron micrograph of branch-like structures of N. hyalinosphaira showing a dense net of pseudopodia, often arranged like trip wires. (C) In situ macro photograph of $N$. antarctikos with attached copepod (arrow). Size of $N$. hyalinosphaira specimen shown $>2 \mathrm{~cm}$

tors of the quality and freshness of organic matter of phytoplankton origin (Wakeham et al. 1997, Fileman et al. 1998).

Multivariate statistical analyses based on the full fatty acid profiles of Astrammina rara and Crithionina delacai revealed a distinct difference in the overall fatty acid composition between the 2 species (Fig. 2). The multidimensional scaling (MDS) plot shows a clear separation between A. rara and C. delacai into 2 distinct groups, which clearly indicates different feeding patterns of the 2 species.

A significant $(p<0.05)$ difference existed between the quantities of the zooplankton marker fatty acids 20:1 (n-9) and 22:1(n-11) found in Astrammina rara early $(4.8 \%)$ compared to late $(2.8 \%)$ in the season (Table 3). These fatty acids occur in large amounts in storage substances (wax esters) of calanoid copepods (Albers et al. 1996), and are also abundant in deep-sea seastars (Howell et al. 2003). They are synthesized de novo by metazoans (Graeve et al. 2005), and neither has been found in phytoplankton to date. These characteristics make 20:1(n-9) and 22:1(n-11) useful biomarkers for metazoan organisms (Falk-Petersen et al. 2000, Auel et al. 2002), and the presence primarily of 20:1(n-9) in A. rara supports earlier observations of carnivorous feeding by this species (Bowser et al. 1992). In an attempt to explain the high amounts of PUFAs also found in $A$. rara, we analyzed 2 co-occurring metazoa from Explorers Cove: an amphipod and a pycnogonid species. The metazoans were found to contain similarly high amounts of PUFAs: $45 \%$ of all fatty acids in the amphipod and $35.5 \%$ in the pycnogonid. The combination of the high amount of PUFAs and the elevated amount of zooplankton biomarker found in A. rara in early November suggests that the PUFAs contained in this species may originate from recently ingested herbivorous metazoans, which in turn were feeding on fresh microalgal material, rather than A. rara feeding on microalgal material directly. This is similar to observations by Cripps \& Atkinson (2000) and Auel et al. (2002), who found high amounts of PUFAs from their food source in zooplankton feeding on herbivorous metazoa.

The relative PUFA content of Astrammina rara and the 2 Notodendrodes hyalinosphaira morphotypes was not significantly different between sampling occasions (early and late in the season). Crithionina delacai was the only one of 3 Explorers Cove species that had a significantly higher relative amount of PUFAs early in the season $(45.5 \%$, on November 7$)$ compared to later (34.2\%, on January 31) (Table 3).

Crithionina delacai displayed an increase in variability within its fatty acid profile on the late season sampling occasion at the end of January, which is indicated by the greater standard deviations (Table 3 ). This suggests a more variable or unselective food intake at that time of year. The amounts of the diatom markers 16:1(n-7) and 20:5(n-3) in Astrammina rara and C. delacai were high and even increased slightly over the austral summer between early November and late January (from 18.9 to $21.8 \%$ in A. rara and from 21.6 to $22.7 \%$ in C. delacai), which indicates the ongoing availability of diatoms throughout the season. It may be problematic to consider $16: 1(n-7)$ as a diatom marker in sedimentary systems, because some bacteria contain large amounts of this fatty acid. However, 
Table 3. Astrammina rara and Crithionina delacai. Seasonal comparison (early summer vs. late summer) of fatty acid profiles (weight $\% \pm$ SD). PUFAs: polyunsaturated fatty acids; C20 (I) and C20 (II): 20C-fatty acids not further identified; $\mathrm{n}=4$ (except $C$. delacai late season, when $\mathrm{n}=3$ ). nd: not detected

\begin{tabular}{|c|c|c|c|c|}
\hline \multirow{2}{*}{ Fatty acid } & \multicolumn{2}{|c|}{ - Astrammina rara -} & \multicolumn{2}{|c|}{ - Critihionina delacai -} \\
\hline & Early season & Late season & Early season & Late season \\
\hline $14: 0$ & $3.7 \pm 1.1$ & $7.4 \pm 1.8$ & $3.3 \pm 0.1$ & $5.7 \pm 1.1$ \\
\hline $15: 0$ & $0.7 \pm 0.2$ & $0.7 \pm 0.2$ & $1 \pm 0.1$ & $2.4 \pm 2.4$ \\
\hline $16: 0$ & $10.7 \pm 3$ & $12.1 \pm 2.2$ & $8.7 \pm 1.2$ & $12.6 \pm 7.9$ \\
\hline $16: 1(n-9)$ & $0.5 \pm 0.2$ & $0.3 \pm 0.1$ & $0.9 \pm 0$ & $0.6 \pm 0.4$ \\
\hline $16: 1(n-7)$ & $11.8 \pm 3.3$ & $13.7 \pm 3.4$ & $9.3 \pm 1.6$ & $12.7 \pm 8.1$ \\
\hline $16: 1(n-5)$ & $1.8 \pm 1.3$ & $1.1 \pm 0.2$ & $1 \pm 0$ & $1.2 \pm 1.1$ \\
\hline $17: 0$ & $1.2 \pm 0.2$ & $1.6 \pm 0.5$ & $0.6 \pm 0.1$ & $1.7 \pm 0.7$ \\
\hline $17: 1$ & $0.9 \pm 0.4$ & $1 \pm 0.2$ & $1 \pm 0.3$ & $1 \pm 0.5$ \\
\hline $16: 4(n-1)$ & $2.6 \pm 0.6$ & $3.4 \pm 0.7$ & $2.4 \pm 0.2$ & $2.5 \pm 0.6$ \\
\hline $18: 0$ & $5.1 \pm 0.2$ & $4.8 \pm 0.4$ & $3.9 \pm 0.2$ & $3.9 \pm 0.4$ \\
\hline $18: 1(n-9)$ & $11.1 \pm 1.6$ & $12.2 \pm 1.2$ & $9.1 \pm 1$ & $9.3 \pm 1.6$ \\
\hline $18: 1(n-7)$ & $2.2 \pm 0.1$ & $1.2 \pm 0.5$ & $0.7 \pm 0.1$ & $0.7 \pm 0.4$ \\
\hline $18: 2(n-6)$ & $2.2 \pm 0.3$ & $1.7 \pm 0.4$ & $2 \pm 0.2$ & $1.5 \pm 0.4$ \\
\hline $18: 3(n-6)$ & $1.9 \pm 0.5$ & $1.1 \pm 0.4$ & $2.2 \pm 0.1$ & $1.5 \pm 0.4$ \\
\hline $18: 3(n-3)$ & $1 \pm 0.2$ & $0.5 \pm 0.3$ & $1.2 \pm 0.1$ & $0.5 \pm 0.3$ \\
\hline $18: 4(n-3)$ & $2.2 \pm 0.3$ & $2 \pm 0.4$ & $2.5 \pm 0.2$ & $1.7 \pm 0.8$ \\
\hline $20: 0$ & $0.8 \pm 0.3$ & $0.4 \pm 0.2$ & $1.4 \pm 0.4$ & $0.7 \pm 0.4$ \\
\hline $20: 1(n-9)$ & $4.7 \pm 0.8$ & $2.8 \pm 2$ & $1 \pm 0.2$ & $1.1 \pm 0.6$ \\
\hline $20: 1(n-7)$ & $1.5 \pm 0.2$ & $0.6 \pm 0.2$ & $2.4 \pm 0.4$ & $2.3 \pm 1.1$ \\
\hline C20 (I) & $1.3 \pm 0.4$ & $0.8 \pm 0.4$ & $7.5 \pm 0.7$ & $7.3 \pm 2.2$ \\
\hline $20: 4(n-6)$ & $10 \pm 2.7$ & $7.7 \pm 2.2$ & $10.3 \pm 0.4$ & $7.1 \pm 1.7$ \\
\hline C20 (II) & $0.4 \pm 0.1$ & $0.3 \pm 0.1$ & $0.7 \pm 0$ & $0.4 \pm 0.2$ \\
\hline $20: 4(n-3)$ & $0.5 \pm 0.1$ & $0.3 \pm 0.1$ & $0.9 \pm 0.1$ & $0.7 \pm 0.5$ \\
\hline $20: 5(n-3)$ & $7.1 \pm 1$ & $8.1 \pm 0.6$ & $12.3 \pm 0.7$ & $10 \pm 4.4$ \\
\hline $22: 0$ & $5 \pm 1$ & $4.8 \pm 1.9$ & $0.7 \pm 0.3$ & $0.7 \pm 1$ \\
\hline $22: 1(n-11)$ & $0.1 \pm 0$ & nd & $0.1 \pm 0.1$ & nd \\
\hline $21: 5(n-3)$ & $0.3 \pm 0.1$ & $0.3 \pm 0.2$ & $2.9 \pm 0.5$ & $2.5 \pm 1.7$ \\
\hline $22: 5(n-3)$ & $0.3 \pm 0.1$ & $0.3 \pm 0.1$ & $0.5 \pm 0.1$ & $0.4 \pm 0.4$ \\
\hline $22: 6(n-3)$ & $6.6 \pm 2.3$ & $7.6 \pm 1.9$ & $8.3 \pm 1.2$ & $5.8 \pm 3.3$ \\
\hline PUFAs & $34.7 \pm 8.2$ & $33.0 \pm 7.3$ & $45.5 \pm 3.8$ & $34.2 \pm 14.5$ \\
\hline
\end{tabular}

levels of the bacterial marker 18:1(n-7) were very low in all 3 species, suggesting that bacteria are not an important part of their diets and that the 16:1(n-7) observed was most likely of diatom origin.

The amounts of PUFAs and the combined bacterial biomarkers 15:0, 17:0 and 18:1(n-7) were relatively similar between the Notodendrodes hyalinosphaira morphotypes (PUFAs: 34.6 and $37.1 \%$; bacterial markers: 3.1 and $2.5 \%$ in the 2 morphotypes). Both morphotypes contained high relative amounts of the diatom marker fatty acids $16: 1(n-7)$ and $20: 5(n-3)$, with $28.6 \%$ in quartz balls and $22.4 \%$ in tree-morphs (Table 4). Only the relative content of metazoan biomarkers differed between the two with 20:1(n-9) accounting for only $0.2 \%$ of total fatty acids in the tree-morph and $5.3 \%$ in the quartz ball, while 22:1(n-11) made up only $0.4 \%$ in the quartz ball, and the tree-morph had none of this fatty acid (Table 4). The 2 morphs differed substantially in their relative amounts of arachidonic acid, 20:4(n-6), with tree-morphs containing $11.2 \%$ and quartz balls only $1.1 \%$.

\section{DISCUSSION}

The remarkably high amounts of PUFAs found in the 3 foraminiferal species examined is an unexpected result, indicating a significant input of carbon from primary production to the benthic community in Explorers Cove. Some Antarctic marine bacteria, the majority of which only occur in sea ice (Nichols \& McMeekin 2002), also produce PUFAs such as 20:5(n-3) (eicosapentaenoic acid), 20:4(n-6) (arachidonic acid) and 22:6(n-3) (docosahexaenoic acid) (reviewed by Russell \& Nichols 1999, Nichols 2003). However, although bacterial densities within sea ice can be considerable (Palmisano \& Sullivan 1983, McGrath Grossi et al. 1984, Sullivan \& Palmisano 1984), they may contribute only $9 \%$ of total carbon production (Kottmeier et al. 1987). In addition, all 3 of the species examined contained only low amounts of the bacterial biomarkers 15:0, 19:0 and 18:1(n-7), indicating that the contribution of bacteria to their diet is, at most, very modest, and that the primary source of the PUFAs is phytoplankton.

The efficiency of prey capture differed among the 3 species, indicating that prey capture is targeted and that prey items do not 'stick' to extended pseudopodia randomly. The fact that there were no prey attached to dead specimens of Pilulina sp. or to specimens of the related protist Gromia sp. in the feeding experiments indicates that prey capture is restricted to the presence of functional pseudopodia of live Foraminifera.

\section{New insights into the autecology of the species examined}

\section{Notodendrodes hyalinosphaira}

The 2 morphotypes of this species have distinctly different fatty acid profiles, which strengthens the premise that they also represent different trophotypes. The observation of higher relative amounts of zooplankton markers in the quartz ball than in the tree-morph of $\mathrm{No}$ todendrodes hyalinosphaira suggests that the ingestion of metazoans plays a more important part in the diet of the quartz ball and is negligible in the tree-morph. It may seem surprising at first that the shallow infaunal 
Table 4. Notodendrodes hyalinosphaira. Comparison of fatty acid profiles (weight \%) of tree- and quartz ball morphotypes. nd: not detected

\begin{tabular}{|c|c|c|}
\hline Fatty acid & Tree-morph & Quartz balls \\
\hline $14: 0$ & 4.0 & 2.9 \\
\hline 15:0 & 1.9 & 0.6 \\
\hline C15 & 1.2 & 2.7 \\
\hline 16:0 & 15.5 & 11.1 \\
\hline $16: 1(n-9)$ & 5.3 & 3.8 \\
\hline $16: 1(n-7)$ & 8.9 & 5.4 \\
\hline $16: 1(n-5)$ & 1.5 & 0.4 \\
\hline $17: 0$ & 0.2 & 0.9 \\
\hline $17: 1$ & 0.2 & 0.4 \\
\hline $16: 4(n-1)$ & 2.6 & 2.6 \\
\hline $18: 0$ & 3.6 & 3.8 \\
\hline $18: 1(n-9)$ & 18.7 & 16.6 \\
\hline $18: 1(n-7)$ & 1.0 & 1.0 \\
\hline $18: 2(n-6)$ & 0.7 & 0.8 \\
\hline $18: 3(n-6)$ & 0.7 & 1.2 \\
\hline $18: 3(n-3)$ & 0.1 & 0.3 \\
\hline $18: 4(n-3)$ & 1.2 & 1.0 \\
\hline $20: 0$ & 0.4 & 0.5 \\
\hline $20: 1(n-9)$ & 0.2 & 5.3 \\
\hline $20:(n-7)$ & 1.0 & 1.8 \\
\hline C20 (I) & 1.6 & 4.6 \\
\hline $20: 4(n-6)$ & 11.2 & 1.1 \\
\hline C20 (II) & 0.2 & 0.4 \\
\hline $20: 4(n-3)$ & 0.1 & 0.4 \\
\hline $20: 5(n-3)$ & 13.5 & 23.2 \\
\hline $22: 0$ & nd & 0.3 \\
\hline $22: 1(n-11)$ & nd & 0.4 \\
\hline $21: 5(n-3)$ & nd & 0.1 \\
\hline $22: 5(n-3)$ & 0.1 & 0.4 \\
\hline $22: 6(n-3)$ & 4.4 & 6.0 \\
\hline PUFAs & 34.6 & 37.1 \\
\hline
\end{tabular}

quartz ball should be feeding on metazoans; however, it is possible that this morphotype extends pseudopodia onto the sediment surface to trap prey, or alternatively that infaunal metazoans are targeted.

The low levels of zooplankton markers in the treemorph of Notodendrodes hyalinosphaira contrast with the highly efficient prey capture observed. Unfortunately, the quartz ball morphotype was not included in the prey capture assay, since the primary goal was to replicate in situ-like conditions, which was only possible by incubating the tree-morph in a sediment core. The 'tree' protrudes above the sediment surface, whereas the quartz ball is infaunal, precluding direct observation. DeLaca et al. (1980) suggested that the related species $N$. antarctikos, which occurs only as a tree-morph, captures small particles from the water column during summer and directly absorbs dissolved organic carbon (DOC) during the less productive times of the year, when less particulate material is present. Even during summer, food capture and digestion occur infrequently (DeLaca et al. 1980, 1981). The low levels of zooplankton markers found in the tree-morph of $N$. hyalinosphaira (we analyzed only early season spe-

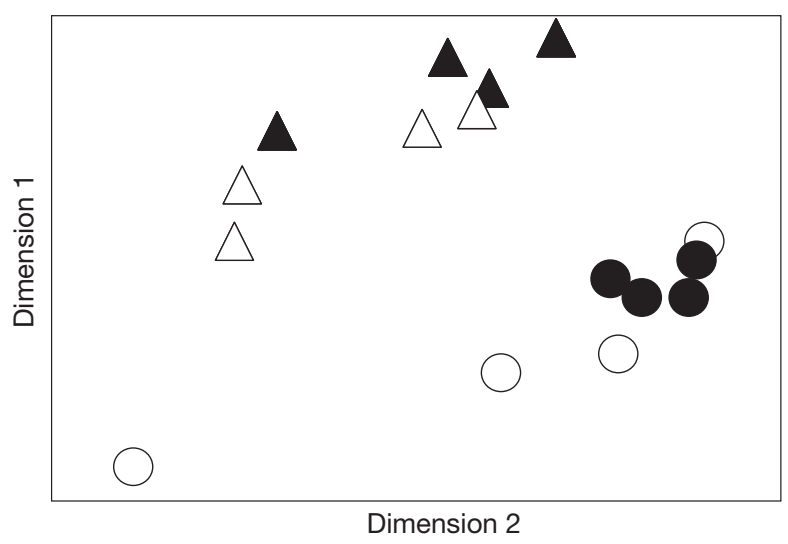

Fig. 2. Astrammina rara and Crithionina delacai. MDS plot of full fatty acid profiles (weight \%, untransformed data; 5 specimens per replicate) of the 2 species from Explorers Cove in early (November 7, 2001) and late (January 31, 2002) austral summer. Stress $=0.05 . \mathbf{\Delta}:$ A. rara (early season), $\bullet:$ C. delacai (early season), $\Delta$ : A. rara (late season), O: C. delacai (late season)

cimens) may be explained simply by the absence or low abundances of metazoans on the sampling occasion.

The high content of 20:4(n-6) observed in the treemorph was 10 times greater than in that of the quartz ball. Arachidonic acid is a major cell membrane constituent in deep-sea organisms and is thought to facilitate low temperature and pressure adaptation in bacteria (Yano et al. 1997) and some temperate and polar marine bivalves (Gillis \& Ballantyne 1999, Hall et al. 2002). The higher relative amount of this fatty acid in the tree-morphs may reflect the greater cell surface area in comparison to the quartz ball, in which the cell forms a simple sphere.

\section{Crithionina delacai}

In conjunction with the comparatively low amounts of zooplankton biomarker found in Crithionina delacai, the significant difference in the content of PUFAs between early and late in the season suggests direct uptake of fresh phytoplankton-derived material. This is consistent with earlier SEM observations of food vacuole contents of this species, which contained diatom frustules as well as detrital material (Gooday et al. 1995), indicating an omnivorous feeding behaviour that includes herbivorous and detrital feeding. This is also consistent with the lower efficiency of prey capture by $C$. delacai in the feeding experiments.

\section{Astrammina rara}

Our results confirm early suggestions of a carnivorous diet for this species (DeLaca 1986), which is 
highly efficient in prey capture (see Fig. 3 in Bowser et al. 1992) and ingests a wide variety of co-occurring metazoa as prey. The presence of zooplankton biomarker in our fatty acid analyses indicates that carnivory occurs in situ, and that the high amounts of PUFAs in this species originate from ingested metazoa, rather than from direct uptake of phytoplankton. Differences in the relative amounts of metazoan biomarker fatty acids found in A. rara early compared to late in the season may indicate enhanced ingestion of metazoans by the Foraminifera on the earlier sampling occasion, or conversely the uptake of consistent amounts of zooplankton throughout the season, with the late season zooplankton containing higher amounts of fresh material from sea-ice primary production.

\section{The benthic environment at Explorers Cove}

The presence of large amounts of PUFAs in the Foraminifera throughout the summer season indicates both the continual availability of fresh organic matter from microalgal primary production at the sampling site during this time, as well as ingestion of this material by all 3 species either directly or indirectly through the capture of herbivorous metazoa. Selective uptake of phytoplankton-derived material high in polyunsaturated fatty acids by benthic Foraminifera in the Antarctic was shown by Suhr et al. (2003) and Suhr \& Pond (2006). There is also evidence from ${ }^{13} \mathrm{C}$ tracer experiments conducted in situ in Sagami Bay, Japan, for ingestion of fresh phytodetrital material (Nomaki et al. 2005). Our new observations suggest that the Explorers Cove site is less oligotrophic, relative to eastern McMurdo Sound, than previous studies suggest (Dayton \& Oliver 1977, Palmisano \& Sullivan 1983, Rivkin \& DeLaca 1990). It seems likely that intense primary production by sea-ice algae and (to a much smaller extent) by sea-ice associated bacteria is the primary source of food for the benthic community in Explorers Cove, which has been suggested for this site by DeLaca et al. (1980) and was later shown to be the case elsewhere in the Antarctic (McMinn 1996, McMinn et al. 2000). The biomass of algae in fast ice

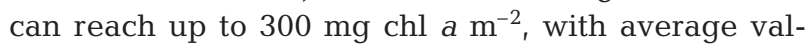

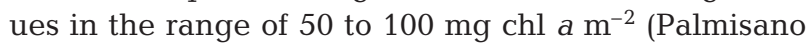
\& Sullivan 1983, Palmisano et al. 1988, Trenerry et al. 2002). High concentrations (40 to $51 \%$ ) of PUFAs were found in sea-ice communities at other sites in McMurdo Sound (Nichols et al. 1993, McMinn et al. 1999), indicating intense primary production below the ice. It is remarkable how closely the relative amount of PUFAs in these studies matched those in the Explorers Cove Foraminifera that we analyzed.
We propose the following pattern for primary production in Explorers Cove: throughout the winter, primary production by shade-adapted benthic microalgae, primarily diatoms (Palmisano et al. 1985, Kottmeier \& Sullivan 1987, Robinson et al. 1995), takes place at low levels, providing food for the benthic community during this period. Beginning in mid to late November, the spring-bloom of ice algae sets in, and increasing concentrations of ice algae that subsequently attenuate light penetrating the ice limit benthic algal production (Palmisano et al. 1987). Throughout the summer, organic carbon is transferred from the ice to the benthic community. By late January, divers in Explorers Cove observed the release of large amounts of organic carbon from ice algal production from the melting sea ice, which are deposited on the seafloor (S. S. Bowser pers. obs.).

\section{Carnivory in Foraminifera}

For over a century, certain planktonic Foraminifera have been known to take metazoan prey such as copepods (reviewed by Bé \& Anderson 1976). Less is known about metazoan carnivory by benthic species, although it has been documented in some sublittoral species (Buchanan \& Hedley 1960). The only review of the topic focuses on the question of whether or not Foraminifera actively kill their prey (Langer \& Bell 1995). Our laboratory feeding experiments expand our knowledge of the range of metazoan prey taken by Astrammina rara, and microscope imagery together with fatty acid biomarker analysis support the interpretation that carnivory occurs in situ and that metazoans are part of the diet of this species. In addition, the entrapment of metazoans by most of the other Foraminifera examined in the feeding experiment indicates that carnivory may be more prevalent within this group than previously believed.

Previous studies on interactions between Foraminifera and metazoan meio- and macrofauna focused on competition between the 2 groups (Chandler 1989) or on the role of large Foraminifera as habitats for metazoa (Levin 1991, Hughes \& Gooday 2004). However, Bernstein et al. (1978) highlighted the impact thatlarge, carnivorous Foraminifera may have on the structure of benthic communities, and our study provides corroborating evidence. The high abundance of large agglutinated Foraminifera in Explorers Cove (Gooday et al. 1996) raises the possibility that predation by large Foraminifera on metazoans (besides competition for resources such as space or food) explains the low macrofaunal densities observed in Explorers Cove by Dayton \& Oliver (1977). The results also suggest that carnivorous Foraminifera may affect settlement pat- 
terns of planktonic larvae of megafauna. This is consistent with the fact that many of the successful megafauna in Explorers Cove, e.g. the bivalve Adamussium colbecki (Stockton 1984) and echinoids (Dayton \& Oliver 1977), have juvenile settling strategies or brood protection behaviors that reduce their contact with benthic predators such as large carnivorous Foraminifera. Similarly, the only larvae not consumed by Astrammina rara in our feeding experiment was Acodontaster sp., which may have effective chemical defenses against predators, as previously shown for most other lecithotrophic offspring of Antarctic asteroids (McClintock \& Baker 1997, McClintock et al. 2003).

Large, monothalamous agglutinated Foraminifera are abundant and presumably play an important ecological role in deep sublittoral and upper bathyal settings in other parts of the world (e.g. Levin et al. 1991, Cedhagen 1993, Gooday et al. 1996, A. J. Gooday pers. obs.). Although information on the role of large Foraminifera in benthic communities is increasing, much work and directed study remain to be done. Future experiments at Explorers Cove (bearing in mind the severe logistical constraints of working out of a remote sea-ice field camp in the Antarctic) could include in situ sediment trays to study the colonization of substrata by metazoan larvae in the presence and absence of Foraminifera, and detailed combined studies of foraminiferal and macrofaunal communities to determine the degree to which large Foraminifera may structure benthic communities on at least the macro- and megafaunal scale.

Acknowledgements. We thank J. Bernhard, T. DeLaca, S. Goldstein, and W. Stockton for helpful discussions, I. Bosch for echinoid larvae, and J. Pawlowski for help with photomicroscopy. We also thank C. Beynon, D. Coons, P. Forte, G. Gwarschaladse, S. Harper, J. Harris, L. Haywood, D. Huang, H. Kaiser, L. Parfrey, N. Pollock, and R. Sanders for diving and/or field assistance. Three anonymous referees and the responsible editor provided very helpful comments on the manuscript. We are indebted to the National Science Foundation, Raytheon Polar Services, and PHI for field logistics. This work was supported by NSF grant ANT-0440769 awarded to S.S.B. S.B.S. was supported through a PhD studentship from the National Oceanography Centre, Southampton, UK.

\section{LITERATURE CITED}

Albers CS, Kattner G, Hagen W (1996) The compositions of wax esters, triacylglycerols and phospholipids in Arctic and Antarctic copepods: evidence of energetic adaptations. Mar Chem 55:347-358

Auel H, Harjes M, da Rocha R, Stübing D, Hagen W (2002) Lipid biomarkers indicate different ecological niches and trophic relationships of the Arctic hyperiid amphipods Themisto abyssorum and T. libellula. Polar Biol 25:374-383

Basov IA (1974) Biomass of benthic foraminfers in the region of the South Sandwich Trench and Falkland Islands. Oceanology 14:277-279
Bé AW, Anderson OR (1976) Gametogenesis in planktonic Foraminifera. Science 192:890-892

Bernstein BB, Hessler RR, Smith R, Jumars PA (1978) Spatial dispersion of benthic Foraminifera in the abyssal central North Pacific. Limnol Oceanogr 23:401-416

Bowser SS, Travis JL (2000) Methods for structural studies of reticulopodia, the vital foraminiferal 'soft part'. Micropaleontology 46(Suppl 1):47-56

Bowser SS, DeLaca TE, Rieder CL (1986) Novel extracellular matrix and microtubule cables associated with pseudopodia of Astrammina rara, a carnivorous Antarctic foraminifer. J Ultrastruct Mol Struct Res 94:149-160

Bowser SS, Alexander SP, Stockton WL, DeLaca TE (1992) Extracellular matrix augments mechanical properties of pseudopodia in the carnivorous Foraminifera Astrammina rara: role in prey capture. J Eukaryot Microbiol 39:724-732

Buchanan JB, Hedley RH (1960) A contribution to the biology of Astrorhiza limicola (Foraminifera). J Mar Biol Assoc UK 39:549-560

Carr MR (2001) PRIMER (Plymouth Routines in Multivariate Ecological Research), Vers. 5.1. Plymouth Marine Laboratory, Plymouth

Cedhagen T (1993) Taxonomy and biology of Pelosina arborescens with comparative notes on Astrorhoza limicola (Foraminifera). Ophelia 37:143-162

Chandler GT (1989) Foraminifera may structure meiobenthic communities. Oecologia 81:354-360

Cripps GC, Atkinson A (2000) Fatty acid composition as an indicator of carnivory in Antarctic krill, Euphausia superba. Can J Fish Aquat Sci 57(Suppl 3):31-37

> Dayton PK, Oliver J (1977) Antarctic soft-bottom benthos in oligotrophic and eutrophic environments. Science 197: $55-58$

DeLaca TE (1982) Use of dissolved amino acids by the foraminifer Notodendrodes antarctikos. Am Zool 22:683-690

DeLaca TE (1986) The morphology and ecology of Astrammina rara. J Foraminifer Res 16:216-224

$>$ DeLaca TE, Lipps JH, Hessler RR (1980) The morphology and ecology of a new large agglutinated Antarctic foraminifer (Textulariina: Notodendrodidae nov.). Zool J Linn Soc 69: 205-224

DeLaca TE, Karl DM, Lipps JH (1981) Direct use of dissolved organic carbon by agglutinated benthic Foraminifera. Nature 289:287-289

> DeLaca TE, Bernhard JM, Reilly AA, Bowser SS (2002) Notodendrodes hyalinosphaira (sp. nov.): structure and autecology of an allogromiid-like agglutinated foraminifer. J Foraminifer Res 32:177-187

Falk-Petersen S, Hagen W, Kattner G, Clarke A, Sargent J (2000) Lipids, trophic relationships, and biodiversity in Arctic and Antarctic krill. Can J Fish Aquat Sci 57(Suppl 3) 178-191

> Fileman TW, Pond DW, Barlow RG, Mantoura RFC (1998) Vertical profiles of pigments, fatty acids and amino acids: evidence for undegraded diatomaceous material sedimenting to the deep ocean in the Bellingshausen Sea, Antarctica. Deep-Sea Res I 45:333-346

Gillis TE, Ballantyne JS (1999) Influences of subzero thermal acclimation on mitochondrial membrane composition of temperate zone marine bivalve mollusks. Lipids 34:59-66

Goldstein ST (1999) Foraminifera: a biological overview. In: Sen Gupta BK (ed) Modern Foraminifera. Kluwer Academic Publishers, Norwell, MA, p 37-55

> Gooday AJ (2002) Organic-walled allogromiids: aspects of their occurrence, diversity and ecology in marine habitats. J Foraminifer Res 32:384-399

Gooday AJ, Levin LA, Linke P, Heeger T (1992) The role of 
benthic Foraminifera in deep-sea food webs and carbon cycling. In: Rowe GT, Pariente V (eds) Deep-sea food chains and the global carbon cycle. Kluwer, Amsterdam, p 63-91

Gooday AJ, Bernhard JM, Bowser SS (1995) The taxonomy and ecology of Crithionina delacai sp. nov., an abundant large agglutinated foraminifer from Explorers Cove, Antarctica. J Foraminifer Res 25:290-298

Gooday AJ, Bowser SS, Bernhard JM (1996) Benthic foraminiferal assemblages in Explorers Cove, Antarctica: a shallow-water site with deep-sea characteristics. Prog Oceanogr 37:117-166

Graeve M, Albers C, Kattner G (2005) Assimilation and biosynthesis of lipids in Arctic Calanus species based on feeding experiments with a ${ }^{13} \mathrm{C}$ labelled diatom. J Exp Mar Biol Ecol 317:109-125

Hall JM, Parrish CC, Thompson RJ (2002) Eicosapentaenoic acid regulates scallop (Placopecten magellanicus) membrane fluidity in response to cold. Biol Bull 202:201-203

Howell KL, Pond DW, Billett DSM, Tyler PA (2003) Feeding ecology of deep-sea seastars (Echinodermata: Asteroidea): a fatty-acid biomarker approach. Mar Ecol Prog Ser 255: 193-206

Hughes JA, Gooday AJ (2004) Associations between living benthic foraminifera and dead tests of Syringammina fragilissima (Xenophyophorea) in the Darwin Mounds region (NE Atlantic). Deep-Sea Res I 51:1741-1758

Kottmeier ST, Sullivan CW (1987) Late winter primary production and bacterial production in seaice and seawater west of the Antarctic Peninsula. Mar Ecol Prog Ser 36: 287-298

Kottmeier ST, Grossi SM, Sullivan CW (1987) Sea ice microbial communities. VIII. Bacterial production in annual Seaice of McMurdo Sound, Antarctica. Mar Ecol Prog Ser 35:175-186

Langer M, Bell CJ (1995) Toxic Foraminifera: innocent until proven guilty. Mar Micropaleontol 24:205-214

Levin LA (1991) Interactions between metazoans and large, agglutinating protozoans: implications for the community structure of deep-sea benthos. Am Zool 31:886-900

> Levin LA, Childers SE, Smith CR (1991) Epibenthic agglutinating foraminiferans in the Santa Catalina Basin and their response to disturbance. Deep-Sea Res 38:465-483

Lipps JH (1983) Biotic interactions in benthic Foraminifera. In: Tevez MJJ, McCall PL (eds) Biotic interactions in recent and fossil benthic communities. Plenum Press, New York, p 331-376

Lipps JH, Valentine JW (1970) The role of foraminifera in the trophic structure of marine communities. Lethaia 3: 279-286

McClintock JB, Baker BJ (1997) Palatability and chemical defense of eggs, embryos and larvae of shallow-water Antarctic marine invertebrates. Mar Ecol Prog Ser 154: 121-131

McClintock JB, Mahon AR, Peters KJ, Amsler CD, Baker BJ (2003) Chemical defences in embryos and juveniles of 2 common Antarctic sea stars and an isopod. Antarct Sci 15:339-344

> McGrath Grossi S, Kottmeier ST, Sullivan CW (1984) Sea ice microbial communities. III. Seasonal abundance of microalgae and associated bacteria, McMurdo Sound, Antarctica. Microb Ecol 10:231-242

McMinn A (1996) Preliminary investigation of the contribution of fast-ice algae to the spring bloom in Ellis Fjord, east Antarctica. Polar Biol 16:301-307

> McMinn A, Skerratt J, Trull T, Ashworth C, Lizotte M (1999) Nutrient stress gradient in the bottom $5 \mathrm{~cm}$ of fast ice,
McMurdo Sound, Antarctica. Polar Biol 21:220-227

McMinn A, Ashworth C, Ryan KG (2000) In situ net primary production of an Antarctic fast ice bottom algal community. Aquat Microb Ecol 21:177-185

Moodley L, Middelburg JJ, Boschker HTS, Duineveld GCA, Pel R, Herman PMJ, Heip CHR (2002) Bacteria and Foraminifera: key players in a short-term deep-sea benthic response to phytodetritus. Mar Ecol Prog Ser 236:23-29

Nichols DS (2003) Prokaryotes and the input of polyunsaturated fatty acids to the marine food web. FEMS Microbiol Lett 219:1-7

> Nichols DS, McMeekin TA (2002) Biomarker techniques to screen for bacteria that produce polyunsaturated fatty acids. J Microbiol Methods 48:161-170

Nichols DS, Nichols PD, Sullivan CW (1993) Fatty acid, sterol and hydrocarbon composition of Antarctic sea-ice diatom communities during the spring bloom in McMurdo Sound. Antarct Sci 5:271-278

Nomaki H, Heinz P, Nakatsuka K, Shimanaga M, Kitazato H (2005) Species-specific ingestion of organic carbon by deep-sea benthic foraminifera and meiobenthos: in situ tracer experiments. Limnol Oceanogr 50:134-146

> Palmisano AC, Sullivan CW (1983) Sea ice microbial communities (SIMCO). 1. Distribution, abundance, and primary production of ice microalgae in McMurdo Sound, Antarctica in 1980. Polar Biol 2:171-177

Palmisano AC, Soohoo JB, White DC, Smith GA, Stanton GR, Burckle LH (1985) Shade adapted benthic diatoms beneath Antarctic sea ice. J Phycol 21:664-667

> Palmisano AC, Beeler SooHoo J, Moe RL, Sullivan CW (1987) Sea ice microbial communities. VII. Changes in under-ice spectral irradiance during the development of Antarctic seaice microalgal communities. Mar Ecol Prog Ser 35: $165-173$

Palmisano AC, Lizotte MP, Smith GA, Nichols PD, White DC, Sullivan CW (1988) Changes in photosynthetic carbon assimilation in Antarctic sea-ice diatoms during spring bloom: variations in synthesis of lipid classes. J Exp Mar Biol Ecol 116:1-13

Pollock NW, Bowser SS (1995) SCUBA collection of benthic Foraminifera in Explorers Cove, Antarctica: an accessible model of the deep-ocean benthos? In: Harper DE (ed) Diving for science. American Academy of Underwater Sciences, Nahant, MA, p 63-74

> Rivkin RB, DeLaca TE (1990) Trophic dynamics in Antarctic benthic communities. I. In situ ingestion of microalgae by Foraminifera and metazoan meiofauna. Mar Ecol Prog Ser 64:129-136

Robinson DH, Arrigo KR, Iturriaga R, Sullivan CW (1995) Microalgal light-harvesting in extreme low-light environments in McMurdo Sound, Antarctica. J Phycol 31: $508-520$

Russell NJ, Nichols DS (1999) Polyunsaturated fatty acids in marine bacteria - a dogma rewritten. Microbiology 145: $767-779$

Smith KL, Baldwin RJ, Karl DM, Boetius A (2002) Benthic community responses to pulses in pelagic food supply: North Pacific Subtropical Gyre. Deep-Sea Res I 49:971-990

Stockton WL (1984) The biology and ecology of the epifaunal scallop Adamussium colbecki on the west side of McMurdo Sound, Antarctica. Mar Biol 78:171-178

Suhr SB, Pond DW (2006) Antarctic benthic Foraminifera facilitate rapid cycling of phytoplankton-derived organic carbon. Deep-Sea Res II 53: 895-902

Suhr SB, Pond DW, Gooday AJ, Smith CR (2003) Selective feeding by benthic Foraminifera on phytodetritus on the western Antarctic Peninsula shelf: evidence from fatty 
acid biomarker analysis. Mar Ecol Prog Ser 262:153-162

Sullivan CW, Palmisano AC (1984) Sea ice microbial communities: distribution, abundance, and diversity of ice bacteria in McMurdo Sound, Antarctica, in 1980. Appl Environ Microbiol 47:788-795

Thiel H (1983) Meiobenthos and nanobenthos of the deep sea. In: Rowe GT (ed) Deep-sea biology. Wiley, New York, p $167-230$

Trenerry LJ, McMinn A, Ryan KG (2002) In situ oxygen

Editorial responsibility: Robert Feller,

Columbia, South Carolina, USA microelectrode measurements of bottom-ice algal production in McMurdo Sound, Antarctica. Polar Biol 25:72-80

- Wakeham SG, Lee C, Hedges JI, Hernes PJ, Peterson ML (1997) Molecular indicators of diagenetic status in marine organic matter. Geochim Cosmochim Acta 61:5363-5369

Yano Y, Nakayama A, Yoshida K (1997) Distribution of polyunsaturated fatty acids in bacteria present in intestines of deep-sea fish and shallow-sea poikilothermic animals. Appl Environ Microbiol 63:2572-2577

Submitted: January 23, 2008; Accepted: August 12, 2008 Proofs received from author(s): October 31, 2008 